\title{
Extracting concentration-invariant odour subspaces through competitive receptor-ligand interactions
}

\author{
Tim C Pearce ${ }^{1 *}$, Manuel A Sanchez-Montanes ${ }^{2}$ \\ From 1st International Workshop on Odor Spaces \\ Hannover, Germany. 4-7 September 2013
}

Robust identification of natural odours poses several difficult problems. First, odours exist in nature as a diversity of mixtures of tens or even hundreds of chemical compounds, with concentrations spanning at least ten orders of magnitude. Thus the olfactory sensory neuron population must be sensitive to a wide variety of stimuli and concentrations while avoiding saturating its response. Second, the animal must identify the odour independently of its concentration over a large range. How these two problems are solved together is not clear. Here we describe how fundamental biophysical mechanisms of receptor-ligand competition account for experimental data reporting nonlinear interactions between mixture compounds at olfactory receptors. We demonstrate how this competition leads naturally to neuronal responses which depend upon the ratios of these mixtures. Our competitive interaction model demonstrates that for high dimensional odour stimuli this ratio coding principle provides an efficient solution to these problems by extracting invariant features that depend on the relative concentrations of the mixture components. Surprisingly, such nonlinear interactions at olfactory receptors are found to simplify the coding of highly dimensional stimuli and may have important consequences for understanding how the olfactory pathway processes complex chemical information.

\section{Authors' details}

${ }^{1}$ Centre for Bioengineering, University of Leicester, Leicester UK. ${ }^{2}$ Ingeniería Informática, Universidad Autónonoma de Madrid, Madrid, Spain.

Published: 16 April 2014

${ }^{1}$ Centre for Bioengineering, University of Leicester, Leicester UK

Full list of author information is available at the end of the article
doi:10.1186/2044-7248-3-S1-09

Cite this article as: Pearce and Sanchez-Montanes: Extracting

concentration-invariant odour subspaces through competitive receptorligand interactions. Flavour 2014 3(Suppl 1):09.
Submit your next manuscript to BioMed Central and take full advantage of:

- Convenient online submission

- Thorough peer review

- No space constraints or color figure charges

- Immediate publication on acceptance

- Inclusion in PubMed, CAS, Scopus and Google Scholar

- Research which is freely available for redistribution
() Biomed Central
C Biomed Central

(C) 2014 Pearce and Sanchez-Montanes; licensee BioMed Central Ltd. This is an Open Access article distributed under the terms of the Creative Commons Attribution License (http://creativecommons.org/licenses/by/2.0), which permits unrestricted use, distribution, and reproduction in any medium, provided the original work is properly cited. The Creative Commons Public Domain Dedication waiver (http://creativecommons.org/publicdomain/zero/1.0/) applies to the data made available in this article, unless otherwise stated. 